www.jmscr.igmpublication.org

Impact Factor 5.84

Index Copernicus Value: 83.27

ISSN (e)-2347-176x ISSN (p) 2455-0450

crossref DOI: _https://dx.doi.org/10.18535/jmscr/v5i7.53

Journal Of Medical Science And Clinical Research

\title{
Clinico-demographic profile of children of age 1-5 years with Malnutrition in Kishanganj district, Bihar
}

\author{
Authors \\ Dr Shabarna Roy ${ }^{1}$, Dr Abhay Kumar ${ }^{2}$, Dr Santosh Kumar ${ }^{3}$ \\ ${ }^{1}$ MBBS,MD (Pediatrics), RMO/Clinical Tutor, R G Kar Medical College, Kolkata \\ ${ }^{2}$ MBBS, MD (Pediatrics) Asso Professor, MGM Medical college \& LSK hospital, Kishanganj, Bihar \\ ${ }^{3}$ MBBS, MD (Pediatrics), Asst Professor (Dept of Pediatrics), MGM Medical College \& LSK Hospital, \\ Kishanganj, Bihar \\ Corresponding Author \\ Dr Santosh Kumar \\ F-110, New Doctors Hostel, MGM Campus, Kishanganj, Bihar \\ Email: santoshaiims08@gmail.com
}

\begin{abstract}
Introduction: Malnourished children, especially in rural area fail to ahieve their full developmental potential.
\end{abstract}

Objective: To study the clinico-demographic profile of children with malnutrition in Kishanganj district, Bihar.

Material and Methods: A total of 250 children aged between 1-5 years were studied in outdoor and indoor department of MGM medical college and LSK Hospital, Kishanganj, Bihar for demographical, clinical and assessment of malnutrition using Indian academy of pediatrics classification (IAP).s

Results: out of total 250 children covered in the present study, male and female children are evenly distributed, 52\% female and 48\% male. In general, age distribution is similar for both the sexes, excepting the fact that female children are relatively more found in 2-3year age group and males in 4-5 yrs group. $72 \%$ of the children were Muslim and $28 \%$ children were Hindu. Children of farmer parents were found more malnourished (42\%). Malnutrition was prevalent in children of illiterate parents (75\%). As per IAP classification for malnutrition, $12 \%$ was found to be normal, $28 \%$ and $26 \%$ was found to be in grade - II and grade - IV malnutrition respectively followed by $20 \%$ in grade III and $14 \%$ in grade - I. Grade II malnutrition was found more prevalent. Maximum percentage of malnutrition seen in 2-3 years and 3-4 years age group. $68 \%$ children were partially immunized, $18 \%$ children were non immunized, $14 \%$ children were immunized. Higher prevalence of malnourished children were observed in partially immunized and non immunized children in comparison to fully immunized children.

Conclusion: Present study concludes that malnutrition is much prevalent in this part of Bihar. - Illiteracy, Low income, unimmunization, high prevalence of $T B$, lack of breast feeding, unemployment create a multifectorial causation of malnutrition. So, this is a major problem in this part and this can be prevented by increasing immunisation coverage, literacy, employment, encouraging breast feeding. This can be done by improvement of female education, health education, administrative support, better health services, and financial support by Govt. and NGOs (Non Government Organisation).

Keywords: Malnutrition; child development; literacy; rural; nutrition 


\section{Introduction}

Malnutrition has been defined "a pathological state resulting from a relative or absolute deficiency or excess of one or more essential nutrients." ${ }^{1} \mathrm{~A}$ well-nourished population is important to a country's long-term development and is a desirable outcome objective in itself. The levels of child malnutrition in India are very high $36.4 \%$ of urban Indian children are underweight, according to the National Family Health Survey 3 (NFHS3). ${ }^{2}$ The nutritional status of an individual is the outcome of a complex interaction of a broad range of host and environmental factors, the latter encompassing physical, biological, and especially sociocultural ones. ${ }^{3}$ Chronic energy deficiency in a similar proportion of adults suggests perpetuation of childhood malnutrition into adulthood. It has been hypothesized that malnutrition affects child development through a number of mediators: child morbidity, amount of energy, motor development, and growth. ${ }^{4}$

Kishanganj is mainly an agricultural district. Most of the people are agricultural workers and daily wagers. Most of the family in these areas are belongs to low socio economic status. This study was intended to do a cross sectional survey on nutritional status of under five children in Kishanganj district.

\section{Material and Methods}

In this cross sectional observation study, a total of 250 children aged 1-5 years were studied in outdoor and indoor department in MGM Medical College and LSK Hospital, Kishanganj between period of from May 2008 to June 2009. Children having any cardiovascular disorder, congenital heart diseases, malignancy and any other major illnesses were excluded. Parameters studied werereligion and sex distribution, socioeconomic status by using modified Kuppuswamy scale, Weight, Length / Height, and severity of malnutrition using IAP classification.

\section{Results}

Out of total 250 children covered in the present study, male and female children are evenly distributed, $52 \%$ female and $48 \%$ male. $42 \%$ children of both sexes are aged between 1-2 y whereas $24 \%$ of them are aged between 4-5 yrs. Rest $34 \%$ is almost equally distributed amongst the other 2 groups. In general, age distribution is similar for both the sexes, excepting the fact that female children are relatively more found in 23 year age group and males in 4-5 yrs group (table 1). Also, statistically as per $\chi^{2}$ test, there is no significant difference between male and female children in terms of age distribution ( $p$ value $=0.0891$ ).

Table 1. Distribution of children according to Age distribution \& sex

\begin{tabular}{|l|c|c|c|c|c|c|}
\hline \multirow{2}{*}{ Age distribution } & \multicolumn{2}{|c|}{ Male } & \multicolumn{2}{c|}{ Female } & \multicolumn{2}{c|}{ Total } \\
\cline { 2 - 7 } & No. & $\%$ & No. & $\%$ & No. & $\%$ \\
\hline $1-2$ yrs. & 50 & 41.7 & 55 & 42.3 & 105 & 42.0 \\
\hline $2-3$ yrs. & 15 & 12.5 & 30 & 23.1 & 45 & 18.0 \\
\hline $3-4$ yrs. & 20 & 16.7 & 20 & 15.4 & 40 & 16.0 \\
\hline $4-5$ yrs. & 35 & 29.1 & 25 & 19.2 & 60 & 24.0 \\
\hline Total & \multicolumn{2}{|l}{$120-100 \%$} & \multicolumn{2}{|l}{$130=100 \%$} & $250=100 \%$ \\
\hline
\end{tabular}

$180(72 \%)$ of the children were Muslim and $70(28 \%)$ children were Hindu. In terms of occupation of parents, farmers are the most frequent $(42 \%)$ followed by $20 \%$ each of the industrial labourer and businessman. Skilled workers were also found to be quite high (18\%) whereas there was hardly any service holder. (table 2)
Table 2 Distribution of children according to occupation of parents

\begin{tabular}{|l|c|c|}
\hline Occupation & $\begin{array}{c}\text { Number of } \\
\text { cases }\end{array}$ & $\%$ of total cases \\
\hline Industrial labourer & 50 & $20 \%$ \\
\hline Farmer & 105 & $42 \%$ \\
\hline Businessman & 50 & $20 \%$ \\
\hline Service & 0 & $0 \%$ \\
\hline Worker of skilled profession & 45 & $18 \%$ \\
\hline Total & 250 & $100 \%$ \\
\hline
\end{tabular}


Malnutrition is prevalent in children of illiterate parents. $75 \%$ of the sample covered were illiterate and $16 \%$ had education at primary level.(table 4$)$

Table 4. Distribution of children according to literacy of parents

\begin{tabular}{|l|c|c|}
\hline Educational status of parents & $\begin{array}{c}\text { Number of } \\
\text { cases }\end{array}$ & $\begin{array}{c}\% \text { of total } \\
\text { cases }\end{array}$ \\
\hline Illiterate & 190 & 74 \\
\hline Primary school & 40 & $16 \%$ \\
\hline Intermediates & 15 & $8 \%$ \\
\hline Graduation and post graduation & 05 & $2 \%$ \\
\hline Total & 250 & 100 \\
\hline
\end{tabular}

Average monthly family income was Rs. 1770. Malnutrition was prevalent in low income group and in lower socioeconomic status. As per IAP classification for malnutrition, $12 \%$ was found to be normal, $28 \%$ and $26 \%$ was found to be in grade - II and grade - IV malnutrition respectively followed by $20 \%$ in grade III and $14 \%$ in grade I. Grade II malnutrition was found more prevalent . Maximum percentage of malnutrition seen in 2-3 years and 3-4 years age group.(table 5)

Table 5 Distribution of children according to Age and Sex following IAP degree of malnutrtion (*\% are within each group)

\begin{tabular}{|c|c|c|c|c|c|c|c|c|c|c|c|c|c|}
\hline \multirow[t]{4}{*}{ Age group } & \multirow{4}{*}{$\begin{array}{l}\text { No. of } \\
\text { children }\end{array}$} & \multirow{3}{*}{\multicolumn{2}{|c|}{ Sex distribution }} & \multicolumn{10}{|c|}{ Direction of \%s horizontal within Male, Female \& combined group } \\
\hline & & & & \multicolumn{10}{|c|}{ Degree of Malnutrition } \\
\hline & & & & \multicolumn{2}{|c|}{ Grade I } & \multicolumn{2}{|c|}{ Grade II } & \multicolumn{2}{|c|}{ Grade III } & \multicolumn{2}{|c|}{ Grade IV } & \multicolumn{2}{|c|}{ Normal } \\
\hline & & $\mathrm{M} / \mathrm{F}$ & $\begin{array}{c}\text { No. }= \\
(100 \%)\end{array}$ & No. & $\%$ & No. & $\%$ & No. & $\%$ & No. & $\%$ & No. & $\%$ \\
\hline \multicolumn{14}{|l|}{ I. Sex wise } \\
\hline \multirow{2}{*}{ Upto 2 yrs. } & \multirow{2}{*}{105} & $\mathrm{M}$ & 50 & 5 & 10.0 & 15 & 30.0 & 15 & 30.0 & 5 & 10.0 & 10 & 20.0 \\
\hline & & $\mathrm{F}$ & 55 & 5 & 9.0 & 15 & 27.3 & 15 & 27.3 & 15 & 27.3 & 5 & 9.1 \\
\hline \multirow[t]{2}{*}{$2-3$ yrs. } & \multirow[b]{2}{*}{45} & $\mathrm{M}$ & 15 & 0 & 0 & 5 & 33.3 & 0 & 0 & 10 & 66.7 & 0 & 0 \\
\hline & & $\mathrm{F}$ & 30 & 10 & 33.3 & 0 & 0 & 5 & 16.7 & 15 & 50.0 & 0 & 0 \\
\hline \multirow[t]{2}{*}{$3-4$ yrs. } & \multirow[b]{2}{*}{40} & $\bar{M}$ & 20 & 5 & 25.0 & 10 & 50.0 & 5 & 25.0 & 0 & 0 & 0 & 0 \\
\hline & & $\mathrm{F}$ & 20 & 0 & 0 & 5 & 25.0 & 5 & 25.0 & 10 & 50.0 & 0 & 0 \\
\hline \multirow[t]{2}{*}{$4-5 \mathrm{yrs}$. } & \multirow[b]{2}{*}{60} & M & 35 & 10 & 28.6 & 15 & 42.8 & 5 & 14.3 & 5 & 14.3 & 0 & 0 \\
\hline & & $\mathrm{F}$ & 25 & 0 & 0 & 5 & 20.0 & 0 & 0 & 5 & 20.0 & 15 & 60.0 \\
\hline \multirow[t]{2}{*}{ Total } & \multirow[b]{2}{*}{250} & $\mathrm{M}$ & 120 & 20 & 16.7 & 45 & 37.5 & 25 & 20.8 & 20 & 16.7 & 10 & 8.3 \\
\hline & & $\mathrm{F}$ & 130 & 15 & 11.6 & 25 & 19.2 & 25 & 19.2 & 45 & 34.6 & 20 & 15.4 \\
\hline \multicolumn{14}{|c|}{ II Male \& Female combined } \\
\hline Upto 2 yrs. & 105 & - & 100 & 10 & 9.5 & 30 & 28.6 & 30 & 28.6 & 20 & 19.0 & 15 & 14.3 \\
\hline $2-3$ yrs. & 45 & - & 100 & 10 & 22.2 & 5 & 11.1 & 5 & 11.1 & 25 & 55.6 & 0 & 0 \\
\hline $3-4$ yrs. & 40 & - & 100 & 5 & 12.5 & 15 & 37.5 & 10 & 25.0 & 10 & 25.0 & 0 & 0 \\
\hline $4-5$ yrs. & 60 & - & 100 & 10 & 16.7 & 20 & 33.3 & 5 & 83 & 10 & 16.7 & 15 & 25.0 \\
\hline Grand total & 2.50 & - & 100 & 35 & 14.0 & 70 & 28.0 & 50 & 20.0 & 65 & 26.0 & 30 & 12.0 \\
\hline With oedema & 250 & - & & - & - & $25^{*}$ & $35.7 *$ & 10 & $20.0^{*}$ & 5 & 7.7 & $*_{-}$ & - \\
\hline
\end{tabular}

Certain specified diseases were found more common in malnourished children.(table) Absence

Table 12.Distribution of children according to diseases

\begin{tabular}{|c|c|c|c|c|c|c|c|c|c|c|c|}
\hline \multirow[t]{3}{*}{ Age group } & \multirow{3}{*}{$\begin{array}{l}\text { No. of } \\
\text { children }\end{array}$} & \multirow{2}{*}{\multicolumn{2}{|c|}{ Sex }} & \multicolumn{8}{|c|}{ Direction of \%s horizontal within Male, Female and combined group } \\
\hline & & & & \multicolumn{2}{|c|}{ ARI } & \multicolumn{2}{|c|}{ Diarrhoea } & \multicolumn{2}{|c|}{$\mathrm{TB}$} & \multicolumn{2}{|c|}{ Normal } \\
\hline & & $\mathrm{M} / \mathrm{F}$ & $\begin{array}{l}\text { No. }= \\
(100 \%)\end{array}$ & No. & $\%$ & No. & $\%$ & No. & $\%$ & No. & $\%$ \\
\hline \multicolumn{12}{|l|}{ I. Sex wise } \\
\hline \multirow{2}{*}{$\begin{array}{l}\text { Upto } 2 \text { yrs. (1-2 } \\
\text { yrs.) }\end{array}$} & \multirow[t]{2}{*}{105} & $\mathrm{M}$ & 50 & 10 & 20.0 & 5 & 10.0 & 30 & 60.0 & 5 & 10.0 \\
\hline & & $\mathrm{F}$ & 55 & 0 & 0 & 15 & 27.3 & 35 & 63.6 & 5 & 9.1 \\
\hline \multirow[t]{2}{*}{$2-3$ yrs. } & \multirow[b]{2}{*}{45} & $\mathrm{M}$ & 15 & 0 & 0 & 5 & 33.3 & 10 & 66.7 & 0 & 0 \\
\hline & & $\mathrm{F}$ & 30 & 5 & 16.7 & 5 & 16.7 & 20 & 66.6 & 0 & 0 \\
\hline \multirow[t]{2}{*}{$3-4$ yrs. } & \multirow[b]{2}{*}{40} & $\mathrm{M}$ & 20 & 0 & 0 & 0 & 0 & 20 & 100.0 & 0 & 0 \\
\hline & & $\mathrm{F}$ & 20 & 0 & 0 & 10 & 50.0 & 10 & 50.0 & 0 & 0 \\
\hline \multirow{2}{*}{$4-5 \mathrm{yrs}$. } & \multirow[b]{2}{*}{60} & $\mathrm{M}$ & 35 & 5 & 14.2 & 15 & 42.9 & 15 & 42.9 & 0 & 0 \\
\hline & & $\mathrm{F}$ & 25 & 5 & 20.0 & 5 & 20.0 & 0 & 0 & 15 & 60.0 \\
\hline \multirow[t]{2}{*}{ Total } & \multirow[b]{2}{*}{250} & $\mathrm{M}$ & 120 & 15 & 12.5 & 25 & 20.8 & 75 & 62.5 & 5 & 4.2 \\
\hline & & $\mathrm{F}$ & 130 & 10 & 7.7 & 35 & 26.9 & 65 & 50.0 & 20 & 15.4 \\
\hline \multicolumn{12}{|c|}{ II Male \& Female combined } \\
\hline Upto 2 yrs. & 105 & - & 100 & 10 & 9.5 & 20 & 19.1 & 65 & 61.9 & 10 & 9.5 \\
\hline $2-3$ yrs. & 45 & - & 100 & 5 & 11.1 & 10 & 22.2 & 30 & 66.7 & 0 & 0 \\
\hline $3-4$ yrs. & 40 & - & 100 & - & - & 10 & 25.0 & 30 & 75.0 & 0 & 0 \\
\hline $4-5$ yrs. & 60 & - & 100 & 10 & 16.7 & 20 & 33.3 & 15 & 25.0 & 15 & 25.0 \\
\hline Grand total & 250 & - & 100 & 25 & 10.6 & 60 & 24.0 & 140 & 56.0 & 25 & 10.0 \\
\hline
\end{tabular}
$(15.4 \%)$ than in males $(4.2 \%)$. 
In our study, out of 250 children, $68 \%$ children were partially immunized, $18 \%$ children were non immunized, $14 \%$ children were immunized. Higher prevalence of malnourished children were observed in partially immunized and non immunized children in comparison to fully immunized children.

Table 14.Distribution of children according to their immunization status

\begin{tabular}{|l|c|c|}
\hline $\begin{array}{l}\text { Immunization status of } \\
\text { children }\end{array}$ & Number of children & $\%$ of total cases \\
\hline Partially immunized & 170 & $68 \%$ \\
\hline Non immunized & 45 & $18 \%$ \\
\hline Immunized & 35 & $14 \%$ \\
\hline Total & 250 & $100 \%$ \\
\hline
\end{tabular}

\section{Discussion}

The present work "Nutritional status of children of 1-5 years age group in district of Kishanganj (Bihar)" was done in Department of Paediatrics MGM Medical College and Hospital, Kishanganj which included 250 children from indoor and outdoor randomly. Observations were done and they are discussed below.

In this study there were 52\% female and $48 \%$ were male. In this, between 1-2 y, 2-3 y, 3-4yr, 4$5 \mathrm{yr}$, males are $41.7 \%, 12.5 \%, 16.7 \%, 29.1 \%$ respectively and females were $42.3 \%, 23.1 \%$, $15.4 \%$ and $19.2 \%$ respectively. $42 \%$ children of both sexes were aged between 1-2 yr whereas $24 \%$ are aged between $4-5$ y. $34 \%$ were almost equally distributed among other groups. In general, age distribution was similar for both sexes excepting females were relatively more found in 2-3 y age group and males in 4-5 years age group. According to S. Chakraborty et al, male and female were $46 \%$ and $54 \%$ respectively in their study. ${ }^{5}$ In my study there is slightly female predominance probably due to small and very selective and random number of children studied. The study of R.N. Mishra et al reported males were $17.59 \%, 20.34 \%, 15.52 \%, 15.52 \%, 22.76 \%$, $23.79 \%$ in $<1 \mathrm{y}, 1-2 \mathrm{y}, 2-3 \mathrm{y}, 3-4 \mathrm{y}, 4-5 \mathrm{y}$ age group and females were $17.39 \%, 17.83 \%, 22.61 \%$, $23.04 \% 19.13 \%$ respectively in the above age group. ${ }^{6}$ Age distribution for both the sexes is statistically similar excepting in 2-3y age group where females are more than male and male in 4-5 y age group which corresponds to my study. ${ }^{57}$

Sumedha Joshi et al et al reported in her study, population consisted of both Hindus and Muslim where Hindus formed a majority. ${ }^{7}$ In my study, there is Muslim predominance probably due to higher percentage of Muslim in this area.

Prevalence of malnutrition has been seen to be higher among children of illiterate parents, in low income group family and in lower socioeconomic class family.

The overall PEM prevalence was seen to be higher among children of illiterate mothers whereas grade II, III, IV PEM was higher among children of mother having primary education. Significant difference $\left(\chi^{2}=12.53, \mathrm{P}<0.05\right)$ was found between percentage of PEM in children of mother who are illiterate or having primary education in comparison to those of having education upto middle school and/ or above. The overall prevalence of PEM was found to be maximum (77.7\%) among those children whose father were labourers and minimum (50\%) among those children whose father were skilled professionals. Grade- I \& grade - II PEM were found among children of labourers, grade - II PEM was maximum in children of businessman $(29.4 \%)$. Significant difference $\left(\chi^{2}=11.04 \quad \mathrm{P}<0.05\right)$ was found in prevalence of PEM among children of labourer/farmers in comparison to those who are in service/business/skilled profession.

Mahesh C. Gupta et al showed in his study a strong relation between nutritional status of subject and educational level of their mothers (P $<0.025){ }^{8}$ Father's education was unrelated to children's nutritional status. The study of Sumedha Joshi et el reported that 54\% mothers were illiterate. ${ }^{7}$ It was seen that education played a significant role in preventing malnutrition in a child. Incidence of malnutrition was higher in female children and in those whose mothers were illiterate. A study in Ethiopia reported that malnutrition is higher among children in household with woman who are less educated 
among boys than among girls, in rural areas than urban areas. Both male and female adult education have a large positive and statistically significant effect on the child's nutritional status and the effect of female education is about twice as large as this of male education. ${ }^{9}$

According to a study of by occupation, heads of household were mostly agricultural labourers (land less) and small independent farmers. 19\% of mothers and $21 \%$ of the fathers were illiterate. $30 \%$ mothers and $21 \%$ fathers had completed only the $3^{\text {rd }}$ grade, $47 \%$ mothers and $51 \%$ fathers completed $6^{\text {th }}$ grade and only $3 \%$ mothers and $6 \%$ fathers had completed junior high school. ${ }^{10}$ Female literacy improves the nutritional status of boys at the cost of girls while higher percapita income improves that of both boys and girls, though the impact is higher for boys. ${ }^{11}$ In my study, mostly parents are farmers or labourers, illiterate, low income earning because this area is underdeveloped and there is no industry so that income can be generated. Most people are daily wagers and they also involve their children in work, so the children can't go to school, so they also remain illiterate and all these factors predispose the children to malnutrition.

In my study, distribution of cases of malnutrition according to IAP classification. In 1-2Y, 3-4Y, 4$5 y$ age group grade I, malnutrition in males are $10 \%(5), 0 \%(0), 25 \%(5), 28.6 \%(10)$ respectively and in females are $9 \%(5), 33.3 \%(10), 0 \%(0)$, $0 \%(0)$ respectively, grade II, malnutrition in males are $30 \%(15), \quad 33 \%(5), \quad 50 \%(10), \quad 42.8 \%(15)$ respectively, in females are $27.3 \%(15), 0 \%(0)$, $25 \%(5)$, respectively, grade III, malnutrition in males are 30\%(15), 0\%(0), 25\%(5), 25\%(5), $14.3 \%(5)$ respectively, in females are $27.3 \%(15)$, $16.7 \%(5), 25 \%(5), 0 \%(0)$ respectively, grade IV, malnutrition in male are $10 \%(5), 66.7 \%(10)$, $0 \%(0), 14.3 \%(5)$, in females are $27.3 \%(15)$, $50 \%(15), 50 \%(10), 20 \%(5)$ respectively were found. $20 \%$ (10) male children between age group $1-2 \mathrm{Y}$ and $9 \%$ (5) female children age group 1-2Y are $60 \%$ (15) female are normal between 4-5Y age group. Percent of grade - II, malnutrition is most prevalent here. Between the sexes, female children were found to be normal (almost double) than males. This is particularly true for grade IV whereas in grade II, males are more prevalent. Oedema is more observed in grade II category, followed by $20 \%$ in grade III and $7.7 \%$ in grade IV, category.

In a study malnutrition and anemia in tribal paediatric population in Purnea District - Bihar, $37.5 \%$ fall in grade I malnutrition where as $84 \%$ falls in grade- III. ${ }^{12}$ According to Nanda $\mathrm{S}$ et al $19.17 \%, 15.28 \%, 8.33 \%$ are of malnutrition grade I, II, III respectively as per IAP classification. ${ }^{13}$ According to a study by $\mathrm{S}$. Chakraborty et al prevalence of malnutrition in- age group 0-1 y. grade 1, II, III, IV malnutrition were 19\%, 19\%, $9.5 \%, 4.7 \%$ respectively. In $1-3$ year, $35.7 \%$, $33.3 \%, 9.5 \%, 4.7 \%$ respectively, in 3-6 year, $27 \%$, $20 \%, 8.1 \%, 4 \%$ respectively. So overall highest malnutrition was observed in 1-3Y age group $(80.9 \%) .^{5}$ In my study highest number of malnutrition is observed in 2-3y and 3-4y age group. Maximum percentage $(66.7 \%)$ of malnutrition in males seen in 2-3y age group (grade IV malnutrition) and maximum $\%$ of malnutrition $(50 \%)$ in females seen in 2-3y age group (grade IV). Grade I and grade IV malnutrition maximum in $2-3 y$ age group. Grade II malnutrition maximum in 3-4y age group and grade III malnutrition maximum in $1-2 y$ age group. High rate at malnutrition in my study is probably due to illiteracy, high birth rate, low income, large family size, ignorance.

In this study, between 1-2y, 2-3y, 3-4y, 4-5y age group $20 \%$ (10), $0 \%$ (0), $0 \%$ (0) $14.2 \%$ (15) males and $0 \%(0), 16.7 \%(5) 0 \%(0), 20 \%$ (5) females suffer form acute respiratory tract infections respectively.

$10 \%$ (5), $33.3 \%$ (5), $0 \%(0), 42.9 \%$ (15) males and $27.3 \% \quad(15), \quad 16.7 \% \quad(5), \quad 50 \% \quad(10), \quad 20 \% \quad(5)$ females were suffering from diarrhoea, respectively, 60\% (30), $66.7 \%$ (10), 100\% (20), 42.9\% (15) males and 63.6\% (35), 66.6\% (20), $50 \%(10), 0 \%(0)$ females suffer from tuberculosis respectively in the above age group. 
$10 \%$ (5), males and $9.1 \%$ (5) females in 1-2 y age group and $60 \%$ (15) females in 4-5 y age group fall into normal category i.e. they have no diseases. So absence of diseases were more common among females.

In a study in Nigeria showed that all 50 children had similar infections. The most common of these were measles (40\%) and gastrointestinal tract infection. However marasmus children had a history of chronic diarrhoea whereas Kwashiorkor children had more acute diarrhoea. ${ }^{14}$ According to a study "Food and agriculture organization, economic and social dept." "The state of food in security in the world 2005'report showed that vast majority of children are killed by neonatal disorder and a handful of treatable infections including diarrhoea, pneumonia, malaria, measles. An Indian study reported that parasites were detected in $17.5 \%$, among these A. Lumbricoides $(68.1 \%)$ and G. Lamblia (32.9\%). ${ }^{15}$ In my study, $100 \%$ male children in 3-4 y age group suffer from $\mathrm{TB}$ and $66.6 \%$ female children suffer from TB in 2-3y age group.

This high prevalence of tuberculosis in my area is due to lack of immunization against TB, lack of proper knowledge about importance of immunization, failure to recieve DOTS therapy, poor immunity of the children due to hunger and malnutrition which predispose the children to different diseases.

Out of 250 children, $68 \%$ children are partially immunized, $18 \%$ children are nonimmunised and $14 \%$ children are immunized. Higher prevalence of malnourished children are observed in partially immunized and non immunized children in comparison to fully immunized.

An Indian study showed after measles immunization significant reductions were observed in 1-4 y old mortality due to diarrhoea and malnutrition. ${ }^{16}$ Another study revealed that a significantly higher prevalence of malnourished children were observed among partially immunized and non immunized children (81.25) and $88.23 \%$ ) in respectively in comparison to fully immunised children $(6.89 \%)$ which corroborate with this study. ${ }^{17}$ A study in Nigeria showed a strong association between severe malnutrition and lack of complete immunization and lack of breast feeding. ${ }^{18}$

Poor immunization coverage increases the risk of mortality and morbidity from vaccine preventable diseases. According to a study in Nigeria no children had been immunized against measles and no children with Kwashiorkor or marasmus had received complete immunization against poliomyelitis. In general, children with Kwashiorkor had received least immunisation. ${ }^{14}$ In this study, maximum percentage of children have not received full immunization, many of them are non immunized. This is due to lack of knowledge about importance of immunization of parents, ignorance, illiteracy, lack of proper training regarding utility of immunization and poor health services and poor accessibility.

\section{Conclusion}

Present study concludes that malnutrition is much prevalent in this part of Bihar. - Illiteracy, Low income, unimmunization, high prevalence of TB, lack of breast feeding, unemployment create a multifectorial causation of malnutrition. So, this is a major problem in this part and this can be prevented by increasing immunisation percentage, illiteracy eradication;, employment, encouraging breast feeding. This can be only done by improvement of female education, health education, administrative support, better health services, and financial support by Govt. and NGOs.

\section{Limitation}

The drawback of the present study include small sample size. As it is a community study it would better if I could take more number of children directly going to community. All cases were taken from hospital OPD and indoor patients.

\section{Conflict of Interest: None}

Funding: None 


\section{References}

1. Jelliffe DB. The assessment of the nutritional status of the community (with special reference to field surveys in developing regions of the world) Monogr Ser World Health Organ. 1966;53:3-271.

2. Ministry of Health and Family Welfare, Government of India. Nutrition in India. National Family Health Survey (NFHS-3). India. 2005-2006.

3. Larson L M, Young MF, Ramakrishnan U, Webb Girard A et al. A Cross-Sectional Survey in Rural Bihar, India, Indicates That Nutritional Status, Diet, and Stimulation Are Associated with Motor and Mental Development in Young Children.J Nutr. 2017 Jun 14. pii: jn251231. doi: 10.3945/jn.117.251231.

4. Chaudhury RN. Determinants of nutrient adequacy in a rural area of Bangladesh. Food Nutr Bull. 1986 8:24-31.

5. Chakraborty $\mathrm{S}$ et al. A study of protein energy malnutrition (PEM) in children (0$6 \mathrm{y}$ ) in a rural population of Jhansi District (U.P.) Indian Journal of community Medicine.2006.Oct-Dec;34(4):291-292.

6. R. N. Mishra et al. " Nutritional status and Dietary Intake of Preschool Children in urban status of Varanasi". Indian Journal of Community Medicine. 2001 Apr-Jun; 26(2):90-93.

7. Joshi S, Walgankar SS. “ Epidemiology of malnuttion in a rural field practice area of Navi Mumbai" Indian Journal of Preventive and Social Medicine. 2004 JanJun; 35(1-2):80-84.

8. Gupta MC, Mehrotra M, Arora S, Saran M. Relation of childhood malnutrition to parental education and mother's nutrition related KAP. Indian J Pediatr. 1991 MarApr;58(2):269-74.

9. Christuensen L, Alderman H. Child malnutrition in Ethiopia: Can maternal knowledge augment due role of Income?
Economic Development and Cultural Change 2004 52:2, 287-312 Oct - 1,2001.

10. Schuftan C, Valenzuela M, LOpez V, Zapata R, Jaque G, Gattas V, Aguayo M.Low School performance: malnutrition or cultural deprivation? Arch Latinoam Nutr. 1975 Jun;25(2):121-34.

11. Pal S .An Analysis of Childhood Malnutrition in Rural India: Role of Gender, Income and Other Household Characteristics. World Development, 27 (7). pp. 1151-1171.

12. Rao TV, Vijay $\mathrm{T}$ et al .Malnutrition and Anemia in Tribal pediatric population of Purnia district (Bihar) .Indian Pediatr. 2006 Feb;43(2):181-2.

13. Nanda S, Mishra CP . Protein energy malnutrition in infants of Varanasi by anthropometric criteria. Indian Journal of preventive and social medicine, 1996 JanJun, 27 (1 \& 2): 11-6.

14. Laditan AA, Reeds PJ..A study of the age of onset, diet and the importance of infection in the pattern of severe PEM in Ibadan, Nigeria. $\mathrm{Br}$ J Nutr. 1976 Nov;36(3):411-9.

15. Awasthi A ,Pande V.K. Prevalence of malnutrition and intestinal parasites in pre school slum children in lucknow. Indian Pediatr. 1997 Jul;34(7):599-605.

16. Kappor S.K. et al.Effectiveness of measles immunisation on diarrhoea and malnutrition related mortality in 1-4 year . Indian J Pediatr. 1991 Nov-Dec;58(6):821-3.

17. Ray S K; Biswas A B; Gupta S D; Mukherjee D et al. Rapid assessment at nutrition status and dietary pattern in municipal area. Indian Journal of community medicine. 2000 Jan-Mar; 25(1): 14-8.

18. Owor M, Tumwine JK, Kikafunda JK..Socioeconomic risk factors for severe protein energy malnutrition among children in Mulago Hspital, Kampala. East Afr Med J 2000 Sep; 77 (9), 471-5. 